\title{
IAMJ
}

INTERNATIONAL

AYURVEDIC

MEDICAL JOURNAL

\section{ROLE OF PANCHKARMA THERAPY IN MANAGEMENT OF DARUNAKA (SEBORRHOEIC DERMATITIS) - A SINGLE CASE STUDY}

\author{
Gourishankar Rajpurohit ${ }^{1}$, Mahesh Kumar Sharma², Gyanprakash Sharma ${ }^{3}$, Anita ${ }^{4}$ \\ ${ }^{1}$ MD scholar, P.G. Dept, Panchkarma, Dsrrau, Jodhpur, Rajasthan, India \\ ${ }^{2}$ Professor \& HOD, P.G. Dept, Panchkarma, Dsrrau, Jodhpur, Rajasthan, India \\ ${ }^{3}$ Associated professor, P.G. Dept, Panchkarma, Dsrrau, Jodhpur, Rajasthan, India \\ ${ }^{4}$ MD Scholar, P.G. Dept, Agad Tantra Evam Vyavhar Ayurveda, Dsrrau, Jodhpur, Rajasthan, India
}

Corresponding Author: gouri.raj728@gmail.com

\section{https://doi.org/10.46607/iamj3909112021}

(Published Online: November 2021)

Open Access

(C) International Ayurvedic Medical Journal, India

Article Received: 25/10//2021 - Peer Reviewed: 05/11/2021 - Accepted for Publication: 06/11/2021

\section{Check for updates}

\section{ABSTRACT}

Dandruff is a common scalp ailment that causes flaking of the skin. It is neither communicable nor dangerous. It can, however, be humiliating and difficult to treat. Darunaka is a Kapalagataroga, but Acharya Sushruta described it as a Kshudraroga due to the vitiation of Vata and Kapha Doshas, with symptoms such as Kandu (itching on the scalp), Keshachyuti (hair loss), Swapa (abnormalities of touch sensation on the scalp), Rookshata (roughness or dryness of the scalp), and Twaksphutana (breaking or cracking of the scalp skin). Seborrheic Dermatitis is an irritative scalp illness characterized by the shedding of dead tissue from the scalp, as well as an itchy sensation. Seborrheic Dermatitis affects roughly $4 \%$ of the population, while dandruff (mild seborrheic dermatitis of the scalp) affects about half of all adults, according to studies. It can begin at any point after puberty and is more common in men. It might lead to social and self-esteem issues. A 25-year-old male patient from Jodhpur came to OPD of Panchakarma, with a chief complaint of Shira Kandu (itching on the scalp), Rukshata (dryness on the scalp), Twaksphutana (cracks in the skin) and Keshachyuti (hair fall). In this case, Ayurvedic formulations and Panchakarma therapy gave the patient till 30 days. The improvement provided by the therapy was assessed based on signs and symptoms before and after the treatment, The therapy's effectiveness was determined by comparing signs and symptoms before and after treatment. For evaluating signs and symptoms, a unique scoring scheme was created. The 
medicine was proven to be both safe and effective at treating signs and symptoms as well as enhancing the general health of the scalp.

Keywords: Darunaka, Shirodhara, Shiro basti, Seborrheic dermatitis

\section{INTRODUCTION}

Darunaka is a Kapalagataroga Roga, according to Acharya Vagbhata ${ }^{[1]}$ and Sarangadhara ${ }^{[2]}$, while Acharya Sushruta ${ }^{[3]}$, Bhavaprakasha ${ }^{[4]}$, and Madhava ${ }^{[5]}$ described it as a Kshudraroga with signs and symptoms of Daruna (cracked scalp), Kandura (itching of the scalp), and Ruksha (dryness of the scalp), among others, due to vitiation of Vata and Kapha. Seborrheic dermatitis is a chronic skin inflammation that causes a red, scaling, sometimes weepy, oozy eruption. Itchy, peeling, or scaling skin, irritation, and pruritus are all symptoms of seborrheic dermatitis, which can affect the scalp as well as other seborrheic areas. ${ }^{[6]}$ Darunaka is caused by non-application of Kesha Taila (head oiling), incorrect cleaning, resting during the day, night vigil, exposure to dust, hot weather, and other conditions, according to Ayurveda texts. Any other studies on genetic, environmental, hormonal, and immune factors. System and environmental factors, lack of normal hygiene such as sebaceous secretions, skin surface fungal colonisation and individual susceptibility all contribute to the pathogenesis of seborrheic dermatitis, according to an Ayurvedic approach to the treatment of darunaka (seborrheic dermatitis). Clinically serious seborrheic dermatitis affects about $3 \%$ of the population, with peak prevalence in the third and fourth decades. ${ }^{\text {[7] }}$

\section{CASE STUDY -}

Centre of study- OPD of Panchakarma department. DSRRAU, Jodhpur, Rajasthan, India. Case report- A 25 yr. old male patient with registration no.36341 came to OPD of Panchakarma department, DSRRAU, Jodhpur, Rajasthan, with chief complaints of-

1. Shira Kandu (Itching on the scalp)

2. Keshabhoomi Rukshata (dryness on the scalp)

4. Keshachyuti (hair fall)

History of present illness- The patient's current disease began two years ago with itching on the scalp. After a few months, he developed a scalp crack with scalp dryness and hair loss. Due to these symptoms, he was under emotional stress and had a disrupted routine. He had also received allopathic treatment, but this had only provided him with brief comfort.

Past sickness history- There was no relevant past disease history.

Family history- No one in the family has ever had such a disease.

Personal history - In table no. 1, personal history is mentioned.

Table 1: Personal history of Darunaka 25years-old, registered patient

\begin{tabular}{|l|l|}
\hline Diet & Mixed diet \\
\hline Micturition & $7-8$ times in a day, 0-2 times in the night \\
\hline Appetite & Moderate \\
\hline Sleep & Disturbed \\
\hline Bowel Habit & Irregular \\
\hline Addiction & No \\
\hline
\end{tabular}

Ashtavidha Pariskha-Ashtavidha Pariskha (Eight-fold classifications) has been mentioned in Table No.2

Table 2: Ashtavidha Pariskha of 25 years registered patient of Darunaka

\begin{tabular}{|l|l|}
\hline Nadi (Pulse) & $68 /$ min \\
\hline Mala (Stool) & $1-2$ times in a day, not satisfactory \\
\hline Mutra (Urine) & $7-8$ times in a day, 0-2 at night \\
\hline Jivha (Tongue) & Sama (Coated) \\
\hline
\end{tabular}




\begin{tabular}{|l|l|}
\hline Shabda $($ Speech) & Spasta (Normal) \\
\hline Sparsha (Touch) & Ruksha \\
\hline Drika (Eyes) & Samanya (Normal) \\
\hline Akruti (Built) & Madhyama \\
\hline
\end{tabular}

Blood Investigation: Blood investigation ( $\mathrm{Hb}$, TLC, DLC, ESR values) of the patient were in normal limits. Treatments are given to the patients-

1. Godanti bhasam ${ }^{[8]}-250 \mathrm{mg}$ and Mukta pisti ${ }^{[9]}$ 250mg- twice in a day

2. Panchtikta Ghrit ${ }^{[10]}$ - twice in a day

3. Arogyavardini vati ${ }^{[11]}$ and Sanjeevani vati ${ }^{[12]_{-}}$ twice in a day

4. Avipattikar churna ${ }^{[13]}$ - twice in a day (before meal)

5. Triphala Guggulu ${ }^{[14]}$ - twice in a day

6. Khadiradiaristh ${ }^{[15]}$ - twice in a day (after meal)

7. Khadira Ghrit ${ }^{[16]}$ and Mahatiktak Ghrit ${ }^{[17]}$ - half teaspoon with milk.
Panchakarma Therapy-

1. Shirodhara ${ }^{[18]}$ - Kashaya Dhara (3 days), Takradhara (4 days) and last Tail Dhara (7 days)

2. Shiro Basti ${ }^{[18]}$ - Mahamarichiyadi Tail (7 days)

\section{Scalp Care-}

1) The patient was advised to take care of his scalp: Always use sterile cold water to wash your head.

2) Avoid using hot water for hair wash.

3) Don't apply heat and direct sunlight on the scalp.

4) Comb hair only after hair gets dried after the wash. RESULTS

After the $15^{\text {th }}$ and $30^{\text {th }}$-day assessments, variations in results were found on each symptom associated with Darunaka. The patient got relief in signs and symptoms with gradual improvement. Assessment on each considering symptoms of Darunaka have been presented in Table no.4

\begin{tabular}{|l|l|l|l|}
\hline Sign and symptoms & $\mathbf{1}^{\text {st }}$ Day (B.T.) & $\mathbf{1 5}^{\text {th }}$ Day (A.T.) & $\mathbf{3 0}^{\text {th }}$ Day (A.T.) \\
\hline Kandu (Itching) & +++ & ++ & - \\
\hline Keshabhoomi Rukshata (Dryness of scalp) & +++ & + & - \\
\hline Twaka Sphutana (Cracking of the skin) & +++ & + & - \\
\hline Keshachyuti (Falling of hair) & +++ & ++ & - \\
\hline
\end{tabular}

\section{DISCUSSION}

Based on the signs, symptoms, and pathophysiology, Darunaka can be linked to seborrheic dermatitis. Ayurvedic classics have discussed a variety of treatments and drugs for treating Darunaka, including Shamashaman chikitsa and Panchakarma therapy. Shiroabhyanga with tail is considered to be beneficial because of its Snigdha Guna qualities, which function through Vatahara, Kaphakara, and Vrishya properties. At the cellular level of the organism, it performs actions such as Snehana, Kledana, and Vishyandana. Godanti bhasam is very effective in chronic fever, headache, heavy bleeding. It acts as a calcium supplement and helps in calcium deficiency disorder. Antacid, Anti-inflammatory, Anti-arthritic, Anti-pyretic, Anti-hypertensive, Demulcent, Anti-mutagenic,
Febrifuge, Hypo-glycemic, Fat Burner, Anti-gout, Muscle relaxant, Antioxidant, Anticancer, Anti-stress, and Antidepressant. Mukta pisti is used in the treatment of mania, psychosis, depression. It acts as a cardiac tonic, antihypertensive, balances rakta and pitta. Panchtikta ghrita helps eliminate toxins from the body and blood purifying. It can treat non-healing ulcers, skin disease, eczema, worm infestations. Triphala Guggulu is an effect on the gastrointestinal tract, maintaining healthy digestion and providing relief from piles, fistula, and inflammatory conditions. It is beneficial in constipation, allergies, haemorrhoids, toxaemia, dullness in skin, controls high blood pressure and acts as an anti-depressant. Mahatiktak ghrita are used to treat skin diseases, bleeding disorders and highly effective ayurvedic medicine in chronic diseases. 


\section{CONCLUSION}

This case report concludes that Ayurvedic management with Panchakarma therapies and internal applied medicines i.e., Shirodhara, Takradhara, Shiro Lepa, shiro basti and many medicines given orally with the care of hair and scalp in daily routine. These methods were found safe and effective in the treatment of $D a$ runaka and improve patients' quality of life. The Ayurvedic management of Darunaka has a strong possibility to break down the pathogenesis of this disease. The recovery in the present case was promising and worth documenting.

\section{REFERENCES}

1. Acharya Vagbhatta. Ashtanga Hridaya. Pandit Hari Sadashiva Sastri, editor. Uttarasthana. 23/23, Varanasi: Chaukhamba Sanskrit Sansthan: 2014.859p.

2. Sarangadhara Sharanghdhar Samhita. Purva khanda 7/151-152, Varanasi: Chaukhamba Orientalia: 2006.116p.

3. Sushruta, Sushruta Samhita. Yadavji Trikamji Acharya, Narayana ram Acharya editor. Nidanasthana.13/35, Varanasi: Chaukhamba Surbharati Prakashan; 2003.322p.

4. Bhavamisra. Bhavaprakasha. K.R. Srikanth Murthy editor.3rd ed. Madhyam Khanda Ksudra roga Adhikar 61/15, Varanasi: Chaukhamba Krishnadas Academy; 2005.654p.

5. Madhava. Madhavanidana. Vidyotini commentary. Yadunandana Upadhyaya editor. Kshudraroga chapter 55/30, Varanasi: Chaukhamba prakashan; 2014. 241242p.

6. Dandruff and Seborrheic dermatitis. A Head Scratcher by James R. Schwartz, Yvonne M. DeAngelis and Thomas L. Dawson, Jr. chapter-12. page no.11. (www.pg science.com cited on 22/03/2020).

7. Johnson MLT. Skin Conditions and Related Need for Medical Care among Persons 1-74 Years, United States, 1971-1974. Series 11, Data from the National Health Survey November, No. 212, DHEW Pub No. (PHS) 79-1660. U.S. Department of Health, Education, and Welfare, Public Health Kumari Archana et.al. An ayurvedic approach in the management of darunaka (seborrheic dermatitis): a case study International Journal of Health Sciences and Research (www.ijhsr.org) 76 Vol.10; Issue: 4; April 2020 Service, National Center for Health, Hyattsville, MD 1978.

8. Pranacharya shreesdanand Sharma, Rastarangini. Pandit Kashinathshastri, editor. Talkasyanamani chapter 11/241, Delhi: Motilal Banarsidas prakashan; 2014.284p.
9. Pranacharya shreesdanand Sharma, Rastarangini. Pandit Kashinathshastri, editor. Ratanvigyaniya chapter 23/72-74, Delhi: Motilal Banarsidas prakashan; 2014.284p.

10. Kaviraj Shree Govind dhassain, Bhaishajyaratnavali, Prof. Siddhinanadan Mishra, editor. Kushtharogadhikar 54/251-254, Varanasi: Chaukhamba Surbharati Prakashan; 2011.884p

11. Kaviraj shree Govind dhassain, Bhaishajyaratnavali, Prof. Siddhinanadan Mishra, editor. Kushtharogadhikar 54/111-117, Varanasi: Chaukhamba Surbharati Prakashan; 2011.871p

12. Sarangadhara. Sharanghdhar Samhita. Madhya khanda 7/18-21, Varanasi: Chaukhamba Orientalia: 2003.197p.

13. Kaviraj Shree Govind dhassain, Bhaishajyaratnavali, Prof. Siddhinanadan Mishra, editor. Amlapitta Adhikar 56/24-28, Varanasi: Chaukhamba Surbharati Prakashan; 2011.903p

14. Sharangdhara. Sarangadhara Samhita. Madhya khanda 7/82-83, Varanasi: Chaukhamba Orientalia: 2003.105p.

15. Kaviraj shree Govind dhassain, Bhaishajyaratnavali, Prof. Siddhinanadan Mishra, editor. Kushtharogadhikar 54/353-358, Varanasi: Chaukhamba Surbharati Prakashan; 2011.895p.

16. Kaviraj shree Govind dhassain, Bhaishajyaratnavali, Prof. Siddhinanadan Mishra, editor. Kushtharogadhikar 54/255-259, Varanasi: Chaukhamba Surbharati Prakashan; 2011.885p.

17. Kaviraj Shree Govind dhassain, Bhaishajyaratnavali, Prof. Siddhinanadan Mishra, editor. Kushtharogadhikar 54/237-243, Varanasi: Chaukhamba Surbharati Prakashan; 2011.883p.

18. 18.Sushruta, Sushruta Samhita. Kaviraj Ambikadatta Shastri, editor. Chikitsasthana 20/30, Varanasi: Chaukhamba Sanskrit Sansthan; 2016.117p

\section{Source of Support: Nil Conflict of Interest: None Declared}

How to cite this URL: Gourishankar Rajpurohit et al: Role Of Panchkarma Therapy In Darunaka (Seborrhoeic Dermatitis) A Single Case Study. International Ayurvedic Medical Journal \{online\} 2021 \{cited November 2021\} Available from: http://www.iamj.in/posts/images/upload/2880_2883.pdf 